\title{
PRADA RODRÍGUEZ, JULIO, THE PLUNDERING OF THE \\ VANQUISHED. THE ECONOMIC REPRESSION DURING EARLY \\ FRANCOISM, PETER LANG, BERLÍN, 2019. 198 PAX. \\ ISBN 978-3-631-78598-0
}

\author{
MARÍA ConCEPción Álvarez Gómez \\ UNED - Ourense
}

Recibido: 29/06/20

Aceptado: $10 / 07 / 20$

Entre os incontables títulos dedicados ao estudo da represión franquista, os que se centran de forma monográfica nos seus aspectos económicos resultan cuantitativamente moi escasos. Aínda así, foron obxecto dunha atención crecente nos últimos anos que vén sumarse ás achegas pioneiras de especialistas como G. Sánchez Recio, C. Mir ou M. Álvaro Dueñas e aos numerosos traballos de índole provincial que dedicaban contadas páxinas á exploración dun fenómeno que esconde realidades moi diversas. De feito, o propio autor xa abordara esta cuestión de forma sucinta na súa tese de doutoramento sobre a provincia de Ourense e, máis recentemente, nunha documentada obra centrada na Comunidade Autónoma de Galicia, a única que xunto con Aragón e Andalucía conta cunha investigación de ámbito rexional.

O autor comeza por abordar a evolución historiográfica sobre esta cuestión, subliñando os factores que, ao seu xuízo explicarían a menor atención dedicada pola historiografía a esta faceta represiva. En primeiro lugar, o feito de resultar moito menos «dramática» que a represión física con resultado de morte ou que o internamento de miles de persoas nos diferentes centros de reclusión utilizados polo réxime, o que fixo que as primeiras investigacións centrásense en elaborar catálogos máis ou menos exactos de vítimas desta modalidade represiva e contextualizar as súas execucións. En segundo lugar, a propia «incomodidade» que representaba para os poderes públicos e para unha parte importante da sociedade o feito de que un bo número de cidadáns atopáranse implicados nun proceso represivo que perseguía privar dos seus bens ou dunha parte do seu patrimonio a persoas que, en ocasións, nin sequera cometeran un delito desde a particular óptica dos sublevados. Finalmente, a propia dispersión das fontes, que contrasta coa crecente apertura e catalogación dos arquivos militares que custodian os miles de sumarios incoados contra os simpatizantes da Fronte Popular. 
A complexidade analítica das diferentes manifestacións da represión económica (subscricións patrióticas, exaccións económicas de diverso tipo e natureza, multas, incautacións de bens e sancións impostas ao amparo da normativa de responsabilidades civís e políticas), a dispersión das fontes e, en ocasións, a escasa precisión das mesmas no relativo a determinadas manifestacións explican a relativa frecuencia coa que unhas e outras aparecen mesturadas nalgunhas publicacións, polo que é de agradecer o esforzo por diferenciar de forma nítida entre elas que realiza o autor nesta monografía. Iso non é obstáculo para que esas diferentes manifestacións, a pesar de ser analizadas de forma individualizada, sexan incardinadas e explicadas polo autor como parte dun único proceso global. De feito, no libro deféndese a tese de que non só integrábanse dentro dun conxunto multidimensional, senón que conformaban un todo con outras modalidades represivas como a represión física, a social, a administrativa, a cultural e mesmo a psicolóxica, incidindo así no carácter sistémico e omnicomprensivo do conxunto do armazón represivo implementado polos golpistas.

Un dos aspectos máis novos é o das « requisas regulamentadas», é dicir, aquelas practicadas polo Exército con todas as formalidades requiridas pola normativa e no exercicio do dereito de requisición que prevían as leis vixentes para situacións nas que estivese declarado o estado de guerra. Non adoita ser común neste tipo de traballos abordar esta problemática, na medida en que, como o autor recoñece, non deberían ser integradas nunha análise sobre a represión económica, polo menos desde o punto de vista conceptual e metodolóxico. Con todo, consideramos que un tratamento sucinto como o que aquí se propón permite recalcar aínda máis ese carácter sistémico e intensivo do conxunto do proceso represivo. Así mesmo, tamén chama a atención a elevada contía das achegas que, a modo de contribucións “espontáneas”, recádanse nas xornadas que seguen á proclamación do estado de guerra e, sobre todo, o feito de que xa desde eses primeiros momentos pódese constatar a extorsión realizada por bandas de milicianos que percorren toda a xeografía rebelde solicitando diñeiro, xoias ou víveres. Non menos interesante resulta a análise da dinámica que leva a substituír as primeiras achegas, se se quere, "desordenadas”, sen ningún tipo de coordinación por diversas autoridades, por un ríxido proceso de centralización a partir da orde da Xunta de Defensa Nacional que establece a Subscrición Nacional e, con posterioridade, polas normas establecidas polo Gobernador Xeral do Estado.

O profundo coñecemento bibliográfico que tamén acredita o autor, a pesar das inevitables omisións que poden detectarse neste tipo de obras, permítelle realizar un breve exercicio comparativo no apartado das responsabilidades civís e políticas que resulta de gran utilidade nunha monografía como a exposta. Estamos, por conseguinte, diante unha obra de gran rigor metodolóxico e analítico que, sen 
dúbida, representa un importante avance no conxunto da historiografía española especializada nesta cuestión. Isto é así non tanto pola novidade das teses que nela deféndense, que en moitos aspectos veñen confirmar outras achegas dos especialistas neste ámbito, senón polo acertado enfoque que se lle deu ao conxunto da represión económica e polo seu tratamento global. 